\title{
Climate Variability and Crop Production in Uganda
}

\author{
Francis M. Mwaura ${ }^{1} \&$ Geofrey Okoboi ${ }^{1}$ \\ ${ }^{1}$ Economic Policy Research Centre (EPRC), Kampala, Uganda \\ Correspondence: Francis M. Mwaura, Economic Policy Research Centre (EPRC), P.O. Box 7841 Kampala, \\ Uganda. Tel: 256-414-541023/4. E-mail: mwaura@eprc.or.ug
}

$\begin{array}{lc}\text { Received: August 7, } 2013 & \text { Accepted: January 28, } 2014 \quad \text { Online Published: March 18, } 2014 \\ \text { doi:10.5539/jsd.v7n2p159 } & \text { URL: http://dx.doi.org/10.5539/jsd.v7n2p159 }\end{array}$

\begin{abstract}
In this paper, the relationship between climate variation and crop output in Uganda for the period 1981 to 2008 is examined. The time-varying ARCH model of the crop production function is used to estimate the relationships. Analysis of the incidence of rainfall and temperature variation from the long-term average indicates that it is insignificant. Estimates of the trend of rainfall and temperature suggest a gradual decline in volume of rainfall and record of temperatures in Uganda in the present and near future. $\mathrm{ARCH}$ model estimates show that a variation in rainfall and temperature from the long-term mean has significant effects on crop output, while exponential increase in rainfall has detrimental effect on crop output. It is recommended that the government should support farmers to adopt small-scale irrigation systems; and capacity of weather forecast agencies should be strengthened to monitor and educate the public on present and potential near-future climate variations.
\end{abstract}

Keywords: climate change, climate variability, agriculture, smallholders, Uganda

\section{Introduction}

Climate change is widely recognised as a major threat to agricultural production and productivity in Uganda as in much of Sub-Saharan Africa. According to the National Development Plan (NDP) and Development Strategy and Investment Plan (DSIP), the direct and indirect impact of climate change on agriculture is pervasive, and if not well managed, may be catastrophic to the economy (Government of Uganda [GoU], 2010; Ministry Agriculture Animal Industry and Fisheries [MAAIF], 2010). The DSIP mentions low crop output and yield as one of the major likely consequences of climate change due to crop destruction by extreme climate events such as floods, storms and drought; loss of farm land and soil nutrients to erosion; and increased incidences of pests and diseases.

Besides agricultural production, climate change which manifests mainly through drastic changes in long term (LT) (Note 1) mean weather (rainfall and temperate) conditions has significant effects on food availability and access through breakdown of the supply infrastructure systems by floods (United Nations Food and Agriculture Organisation [FAO], 2008). Yet, studies on climate change and its impacts on Uganda's economy in general and food security in particular are limited. Nonetheless, even the existing studies on climate change in Uganda (Oxfam, 2008; Hepworth \& Goulden, 2008) focus more on explaining the likely impact of climate change without providing an adequate explanation of the very existence of climate change. Besides, policy documents such as the NDP and DSIP allude to but do not provide adequate information on the occurrence and extent of climate change. While the climate change is a long-term phenomenon, Oxfam use qualitative interviews to explain the impact of climate change in Uganda while Asiimwe and Mpuga (2007) use pooled cross-sectional data to examine effect of rainfall shocks on household income and consumption in Uganda. Although these studies generate interesting findings, they do not address the direct relationship between climate variability and crop output.

This paper addresses the shortcomings in analytical literature about climate change in Uganda by using a relatively longer time-series data on rainfall and temperature to analyse magnitude and incidence of climate variability in Uganda and its associated impact on agricultural production. The data allows for the estimation of the cyclical trend of rainfall and temperature occurrence, which affords the prediction of the likely trend of rainfall and temperature in the near future. Specifically the paper seeks to assess the magnitude of rainfall and temperature variation over the past three decades; examine the cyclic pattern of rainfall and temperature variation; and establish the effect of rainfall and temperature variation on crop production. 
The rest of the paper is organized as follows. Section 2 provides a brief survey of literature on climate change and its effect on agricultural production. The data and empirical model specification is discussed in Section 3 while the results are presented and discussed in Section 4. Section 5 concludes and suggests policy implications.

\section{Literature Review}

Most analyses of the impacts of climate change that have influenced United Nations Framework Convention on Climate Change (UNFCCC) agreements focused on medium to long term projection of carbon emissions and forecasting models of global warming, and cover mainly countries and regions for which relevant data are readily available. Africa is left out due to insufficiency of data and costly omissions (FAO, 2008). At the same time, Africa has been predicted as the most vulnerable to climate change impacts and the most poorly prepared for mitigation (Odongo, 2008). Furthermore the continent is so diverse that each country need to establish specific threat to its nationals and initiate relevant interventions be they policies, management or/and investments to ameliorate the impacts (World Bank, 2010).

Impacts of climate change are already being experienced in Africa (UNEP, 2010); there are prolonged and intensified droughts in eastern Africa; unprecedented floods in western Africa; depletion of rain forests in equatorial Africa; and increased ocean acidity around Africa's southern coast. Vastly altered weather patterns and climate extremes threaten agriculture production and food security, health, water and energy security, which in turn undermine Africa's ability to grow and develop (World Bank, 2009; World Bank, 2010; UNEP, 2010). Although existing literature especially those which were prepared to enlighten the Copenhagen Conference were successful in the agenda of the forum, issues that relate to weather and climatic factors need to be clearly distinguished and thoroughly analysed to guide countries on policy interventions (Odongo, 2008).

Review of the annual national Statistical Abstract indicate a pattern of occurrence of droughts and famine in Uganda (UBoS, 2009) which appear to have a predictable pattern and coinciding with those reported among Uganda's neighbours mostly Kenya (Mogaka et al., 2009) and Ethiopia (Kissi, 2000). In Kenya, rainfall variability which is associated with incidences of seasons' droughts and those of flood has been reported with each of those incidences resulting to detrimental effects to the economy (Mogaka et al., 2009). Twenty-three incidences of major droughts has been identified in the last century in Kenya, with the major seasons of flooding identified as 1961 and 1997/8. Although the Uganda's trend of droughts have not been studied, their impact on the economy have been devastating especially for agricultural sector that remain the mainstay of the economy (UBoS, 2009) and a major poverty reduction strategy (GoU, 2010). It is therefore important to intervene on the issue of climate related changes for the welfare of the country's increasing population (GoU, 2010) and considering that a one percentage point of agricultural performance growth in developing countries, has been associated with an increase in the consumption of poorest third of the population by four to six percentage points (Logen \& Sadoulet, 2007)

Literature on the magnitude of climate change in Africa show that between 1900 and 2000, temperature in the African region may have increased by $1{ }^{\circ} \mathrm{C}$ (Intergovernmental Panel on Climate change [IPCC], 2007).Country specific studies on climate variation are however few. In the case of Uganda, it seems no study has provided a definitive magnitude of temperature as well as rainfall variation. Much of the literature including Oxfam (2008), associate temporal incidences of rainfall and temperature variation -leading to floods or drought, to climate change. Perhaps it is only Hepworth and Goulden (2008) that caution about misinterpreting climate trends as climate change.

A number of studies have attempted to assess/predict the potential effect of climate change on agricultural production. Using cross-sectional household survey data and the Ricardian model, Kabubo-Mariara and Karanja (2007) estimated the economic impact of expected adverse changes in climate on crop farming in Kenya. Their estimates show that increase in summer temperatures have a negative effect of crop revenue of farmers while increase in winter temperatures has a positive relationship with crop revenues. Following approach similar to Kabubo-Mariara and Karanja (2007), Benhin (2008) estimates of the potential impact of climate change on revenue of South African farmers found that a 1 percent increase in temperature would increase the farmers' net crop revenue while a $1 \mathrm{~mm} /$ month fall in precipitation would lead to a fall in net crop revenue.

Using the generalized maximum entropy (GME) estimator on cross-sectional data, Akpalu et al. (2008) examined the effect of climate variability proxied by mean precipitation and temperature on maize yield in South Africa. Increased precipitation and temperature was found to have a positive impact on yield. Farmer use of irrigation was also found to positively influence yield. Schlenker and Lobell (2010) showed that by combining historical crop production and weather data into a panel analysis, a robust model of yield response to climate 
change for maize, sorghum, millet, groundnut, and cassava could be arise. High probabilities of yield losses were predicted for all the crops except cassava slight changes in weather factors in the sub-Saharan Africa.

Moula (2008) is perhaps one of the few studies that have used longer time-series data of rainfall and temperature -spanning 40 years to analyze the impact of climate change on Cameroon's agriculture. Results of his study indicate that 1 percent standard deviation in rainfall and temperature from the long-term mean has a negative effect on output. What is not clear from the author's explanation however is whether the deviation from the mean was positive or negative. Besides climate variability, Moula (2008) reported that increase in labour, fertiliser and irrigation use had increasingly large effects on output.

Oxfam (2008) solicited the views of key stakeholders in Uganda's agriculture and other sectors on climate change and its impact on their livelihood. The responses of interviewees, although interesting do not provide any measurement of the extent to which climate change can be considered responsible to the respondents' productivity woes chronicled in the report.

From the foregoing literature, it is clear that though some work on climate change has been done in Uganda, none is strongly biased in the first instance to explaining the every aspect climate, let alone examining the effect of climate variability on crop agriculture and moreover using long term data. These gaps provide the entry point of this study.

\section{Data and Methods}

\subsection{Data}

Time-series data of 28 observations ranging from 1981 to 2008 was used in this study. The data, which is for variables including rainfall, temperature, cultivated area, output, labour and government budget allocation as a proxy for capital is derived from various sources.

Data on rainfall and temperature were obtained from the Uganda Meteorological department while data on agricultural production (area cultivated and output) were derived from FAO statistics (http://faostat,fao.org). Data on government budget allocation to agriculture was derived from various books of the national Statistical Abstracts (Uganda Bureau of Statistic [UBoS], 2009, 2008) and Background to the Budget (Ministry of Finance, Planning and Economic Development [MoFPED], 2010). Government budget allocation was taken to represent public as well as total capital expenditure in agriculture, as data on private capital investment in agriculture was not available. Finally, data on the proportion of labour employed in Uganda's agricultural sector over the period under investigation is derived from sources including Africa Statistical Year Book (1997) and national Statistical Abstracts.

Summary statistics of the variables are given in Table 1 . The statistics indicate that the long term average rainfall was $1251 \mathrm{~mm}$ per annum, with a minimum of $1032 \mathrm{~mm}$ and a maximum of $1447 \mathrm{~mm}$ per annum. The long term temperature averaged $22.6^{\circ} \mathrm{C}$. Annual climate data (rainfall and temperature) given in Table 1 is derived by summing up monthly data for each weather station into total annual values, which are then averaged for the annual national average. The weather stations from which monthly and annual data was collected include Masindi, Kampala, Entebbe, Kabale, Gulu, Soroti, Tororo, Mbarara, Kasese and Jinja. Although the Bartlett's test for the weather factors among stations showed differences in their means and consequential stations comparisons (Bonferroni test) showed significant differences between some few stations (see Appendix 1), the data was however made to a national average as it represented all the country's six climatic zones (see appendix 2). Besides all the other variables data were only available summed up to a national level. Furthermore Uganda is a small country astride the equator with its rainfall patterns entirely influenced by monsoon wind across the Indian Ocean (NEMA, 2009). Average temperature data was adopted as both maximum and minimum are collected at extreme ends. While maximum daily temperature has not been observed to change, minimum daily temperature has been associated with accelerating temperature rise in East Africa (Christy et al., 2009). Yet the minimum daily temperature reading are heavily influenced by the environment around the station (Horton, 1995).

Between 1981 and 2008, the average area under agriculture was 5,514 million hectares (mha) while total crops' outputs averaged 2 trillion tonnes. The maximum area cultivated and output harvested was 7,191 million acres and 2.6 trillion tones while the lowest area cultivated and output harvested was 5,514 million acres and 1.3 trillion tonnes respectively. Government budget allocation to agriculture over the 28 year period averaged UGX 38.3 billion, with a wide variation as observed between the lowest (UGX 0.039 billions) and the highest (UGX 223 billion). On average 7.6 million adults were working in agriculture with the minimum and maximum number of adults at 5.6 million and 10.6 million, respectively. 
Table 1. Descriptive statistics

\begin{tabular}{lllll}
\hline Variable & Obs & Mean & Min & Max \\
\hline Rainfall (mm per annum) & 28 & 1250.5 & 1032 & 1447 \\
Temperature (degrees Celsius) & 28 & 22.63 & 22.3 & 23.2 \\
$\begin{array}{l}\text { Total crop area (million hectares) } \\
\text { output (100 Million tonnes) }\end{array}$ & 28 & 5513.84 & 3769.6 & 7191.3 \\
$\begin{array}{l}\text { Agriculture Budget (UGX billions) } \\
\begin{array}{l}\text { Agriculture labour force (Adult } \\
\text { population in Agriculture in millions) }\end{array}\end{array}$ & 28 & 19623.95 & 13196.8 & 25845.9 \\
$\begin{array}{l}\text { Reconstruction dummy (Before 1987 } \\
=0 ; \quad 1987 \text { and after =1) }\end{array}$ & 28 & 38.294 & 0.39 & 223.220 \\
\hline
\end{tabular}

\subsection{Model Specification}

The analysis is based on Engle's (1982) time-varying autoregressive conditional heteroskedasticity (ARCH) model and the subsequent extension to the generalized ARCH (GARCH) by Bollerslev (1986). While ARCH models have been widely used in analyzing financial time-series (Bollerslev \& Wooldridge, 1992), of recent, variants of the $\mathrm{ARCH}$ model have been applied in the analysis of climate dynamics and its associated impact on the economy (Campbell \& Diebold, 2003). The use of the ARCH model is motivated by the high level of volatility observed in the climate data, and to some extent, output data (Figures 1,2, 3 \& 3). Volatility suggests that the variables are serially correlated and hence not stationary. Besides, volatility implies that the time-series observations are non-linear, and this is well represented by ARCH models.

$\mathrm{ARCH}$ models are specifically designed to model and forecast conditional variances, such that the variance of the dependent variable as a function of past values of the dependent and exogenous variables. The standard $\operatorname{GARCH}(1,1)$ specification is given as:

$$
\begin{gathered}
Y_{t}=\gamma X_{t}+\varepsilon_{t} \\
\delta_{t}^{2}=\omega+\alpha \varepsilon_{t-1}^{2}+\beta \delta_{t-1}^{2}
\end{gathered}
$$

Where (1) is the standard conditional mean equation of an agricultural production function $(\mathrm{Y})$ written as a function of exogenous variables $(X)$ including natural resources such as land, rainfall and temperature; and physical resources such as labour and capital. The parameter(s) to be estimated and an error term are given as $\gamma$ and $\varepsilon$ respectively. Whereas (2) is the conditional variance equation written as a function of three terms, namely: the mean variance $(\omega)$; the lag of the squared residual from (1) (the ARCH term), which gives information about volatility in the previous period; and last period's variance (the GARCH term). GARCH $(1,1)$ refers to the presence of the first-order ARCH term (the first term in the parentheses) and the first-order GARCH (the second term in the parentheses)

We estimate a non-linear production function stated as:

$$
\begin{gathered}
y_{t}=\gamma_{0}+\gamma_{1} R_{t}+\gamma_{2} T_{t}+\gamma_{4} A_{t}+\gamma_{5} L_{t}+\gamma_{6} K_{t}+\gamma_{7} R_{t} * R_{t}+\gamma_{8} T_{t}^{*} T_{t}+\gamma_{9} R_{t} * T_{t}+Z_{t}+\varepsilon_{t} \\
\delta_{t}^{2}=\omega+\alpha \varepsilon_{t-1}^{2}+\beta \delta_{t-1}^{2}
\end{gathered}
$$

Where: 


\begin{tabular}{llc}
\hline Parameter & Explanatory notes & $\begin{array}{c}\text { Unit of } \\
\text { measure }\end{array}$ \\
\hline$y$ & Output deviation from the mean & $\mathrm{mm}$ \\
$R$ & Rainfall deviation from the mean & ${ }^{\circ} \mathrm{C}$ \\
$T$ & Temperature deviation from the mean & mha \\
$A$ & Area cultivated, deviation from the mean & millions \\
$L$ & Labour employed in agriculture, deviation from the mean & $\mathrm{UGX}$ billions \\
$K$ & Government budget allocation to agriculture, deviation from the mean & $(\mathrm{mm})^{2}$ \\
$R^{*} R$ & Interaction term of rainfall deviation from mean & $\left({ }^{\circ}\right)^{2}$ \\
$T^{*} T$ & Interaction term of temperature deviation from mean & $(\mathrm{mm})\left({ }^{\circ} \mathrm{C}\right)$ \\
$R^{*} T$ & Interaction term of rainfall and temperature deviations from mean & Dummy \\
$Z$ & Dummy variable ( $Z=0$ for period $1981-1986$, representing the period of & $0 ; 1$ \\
& economic breakdown due to war; and $Z=1$ for period $1987-2008$, & \\
$\varepsilon$ & representing period of reconstruction after war) & \\
$\gamma$ & Stochastic term & \\
$\alpha$ & parameters of the conditional mean to be estimated & \\
$\beta$ & ARH parameter to be estimated & years \\
$t$ & GARCH parameter to be estimated & \\
\hline
\end{tabular}

The deviation of the variable (e.g. R) observation from the mean is calculated using the z-distribution function given as:

$$
\text { Rain_Dev }=\frac{(R-\bar{R})}{\delta}
$$

Where $\mathrm{R}$ is actual rainfall, $\bar{R}$ is average annual rainfall, $\delta$ is the standard deviation of rainfall. The rest of the values of the variables T, A L and K in (3) are derived using the Z-distribution estimator (5).

Equations 3 and 4 are estimated following the Bollerslev and Wooldridge (1992) quasi-maximum likelihood (QML) method. The QML method leads to robust standard errors and covariances. Postestimation or residual tests are also carried out to test for any residual serial correlation in the model. These tests include the ARCH Langrage Multiplier (LM) test and the Correlogram Q-statistic test.

\section{Results and Discussion}

\subsection{Climate Variability}

Figure 1 shows the actual and trend of average rainfall received as well as the 28-year average amount received in Uganda between 1981 and 2008. The amount of rainfall received varied and formed some cyclic pattern of lows and highs over the years. Between 1981-1985; 1991-1992; and 2002-2004, rainfall received was below the duration average of $1251 \mathrm{~mm}$ per annum while between 1986 -1990; and 1993-2001, the rains received appear to be higher than the long-term average. The fitted trend line suggests an overall increase in rainfall for the period under review, but the net variation from the long-term average is nil (Table 2). 


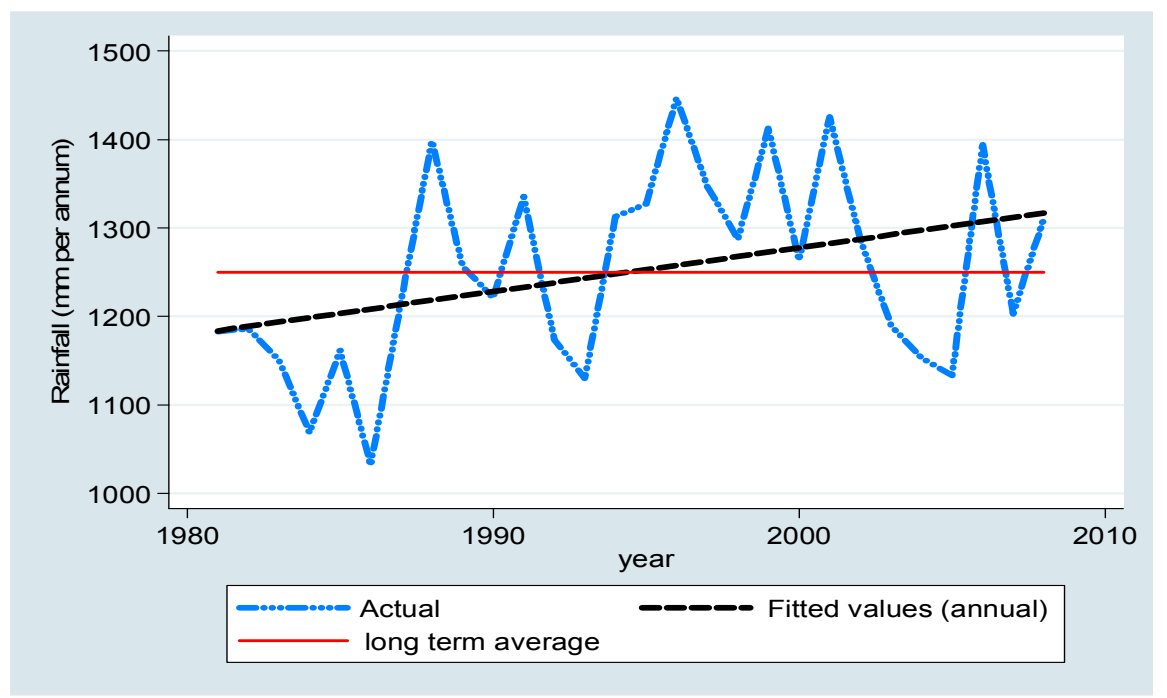

Figure 1. Actual and average rainfall received in Uganda between 1981 and 2008

Source: Authors' calculations based on data.

Figure 2 shows the actual and trend of average temperature recorded as well as the 28 year average temperature record in Uganda between 1981 and 2008. Between 1981 and 1998 average temperatures recorded were below the durational average of $22.6^{\circ} \mathrm{C}$. After 1998, annual average temperatures except for 2001 appear to be higher than the long-term average. The fitted trend line suggests an overall increase in temperature for the period under review, and the net variation from the long-term average is $0.14{ }^{\circ} \mathrm{C}$ (Table 2).

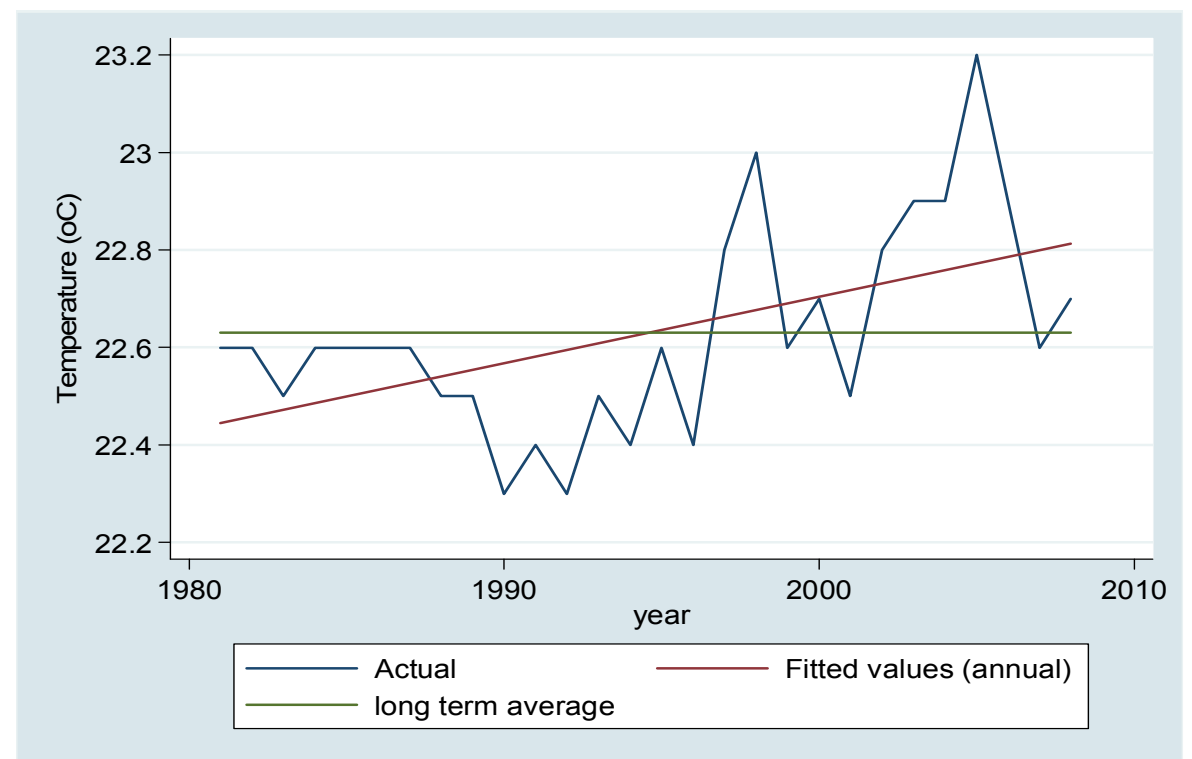

Figure 2. Actual and average temperature recorded in Uganda between 1981 and 2008

Source: Authors' calculations based on data.

Table 2 shows the deviation of the rainfall and temperature from the long-term (LT) average. As earlier explained, there appears to be no substantial deviation of annual rainfall from the 28 -year average except for minimum and maximum deviations of $10.5 \mathrm{~mm}$ and $9.4 \mathrm{~mm}$ from the LT average, which is even less than 1 percent deviation. However, in the case of temperature variation, results reveal that the temperature has increased by $0.14{ }^{\circ} \mathrm{C}$ (or 0.6 percent) above the 28 -year average. The minimum and maximum deviations from 
the LT average is $-1.43{ }^{\circ} \mathrm{C}$ and $2.86{ }^{\circ} \mathrm{C}$, which is 6.2 percent reduction and 12.7 percent increase from the LT average.

Table 2. Rainfall and temperature variation, $1981-2008$

\begin{tabular}{llllll}
\hline Climate variable & Obs & Mean & Std. Dev. & Min & Max \\
\hline Rainfall (mm per annum) & 28 & 1250.50 & 110.47 & 1032.00 & 1447.00 \\
Rainfall variation from mean - & 28 & 0.00 & 5.29 & -10.45 & 9.40 \\
Temperature (degrees Celsius) & 28 & 22.63 & 0.21 & 22.30 & 23.20 \\
Temperature variation from mean & 28 & 0.14 & 1.01 & -1.43 & 2.86 \\
\hline
\end{tabular}

Source: Authors' calculations based on data.

\subsection{Cyclical Pattern of Rainfall and Temperature}

Figure 3 traces the long-term cyclical trend of rainfall and temperature using the Hodrick-Prescott Filter (Note 2) (Hodrick \& Prescott, 1997). The rainfall graph indicates that for the period under review, rainfall peaked to an average $1300 \mathrm{~mm}$ in mid 1990s having risen gradually from about $1100 \mathrm{~mm}$ in early $1980 \mathrm{~s}$. From the peak value in 1998, rainfall intensity has continuously declined and appears to continue for some time till it hits the bottom of the cycle before rising up again. A causal inspection suggests that Uganda's rainfall cycle from low to high and vice-versa may take 20 years, e.g. from $1978-1998$ for the low to high. From this causal observation, it is suggestive that rainfall intensity that started declining from 1998 is yet to hit the bottom possibly in 2018 before increasing again.
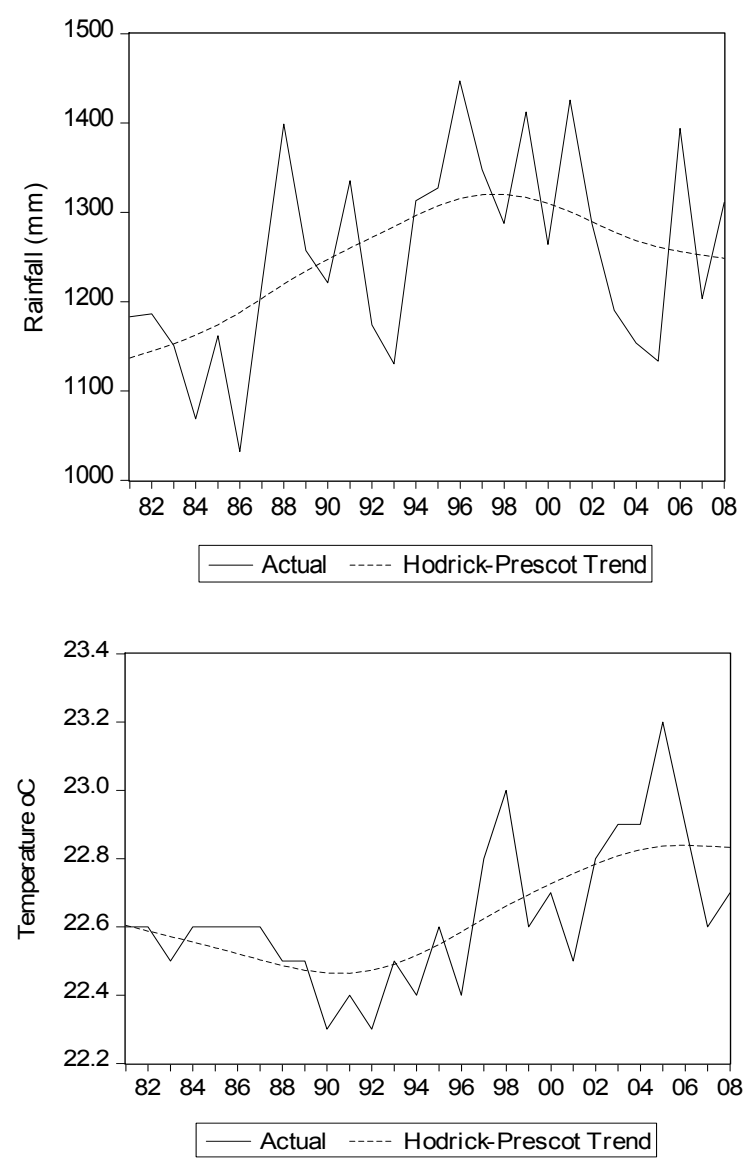

Figure 3. Cyclical trend of rainfall and temperature, 1981-2008

Source: Authors' calculations based on data. 
Looking at the temperature graph, the cycles appear to be shorter compared to rainfall. For example it took about 15 years for temperature to rise from the lowest observed (trough) in 1991 to the highest average in 2005. And in the present, temperatures appear to be gradually declining and the trend may continue for a while.

\subsection{Climate Variation and Output-Graphical}

Figure 4 depicts the relationship between deviation in aggregate output and changes in rainfall and temperature from the long-term mean. The graphical observations show a possible relationship especially between rainfall and agricultural production. It shows that between 1981 and 1990, generally negative deviations in rainfall were also associated with negative deviation in output. While somewhat positive deviations in rainfall and temperature were associated with positive deviation in agricultural output.

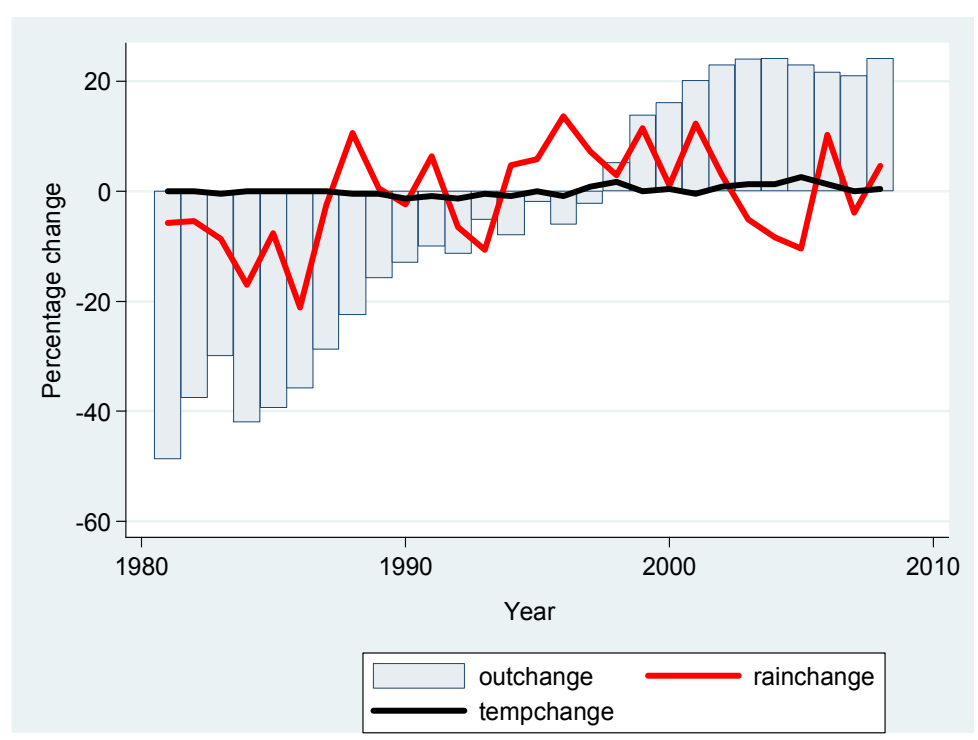

Figure 4. Rainfall and temperature variability and crops' output

Source: Authors' calculations based on data.

\subsection{Econometric Results}

\subsubsection{Unit Root Test}

Table 3. Augmented Dickey-Fuller (ADF) test for stationarity

\begin{tabular}{lccc}
\hline \multirow{2}{*}{ Variable } & \multicolumn{2}{c}{ ADF Test Statistic } & \\
\cline { 2 - 3 } & level & First diff & Level of integration \\
\hline Output & -0.514 & -4.421 & $\mathrm{I}(1)$ \\
Rainfall & -3.540 & & $\mathrm{I}(0)$ \\
Temp & -2.55 & -6.94 & $\mathrm{I}(1)$ \\
Area & -0.49 & -6.31 & $\mathrm{I}(1)$ \\
Labour & 17.10 & & $\mathrm{I}(0)$ \\
Budget & 0.64 & -5.09 & $\mathrm{I}(1)$ \\
Critical value at 5\% & & & \\
level & -2.975 & -2.979 & \\
\hline
\end{tabular}

Source: Authors' calculations based on data. 
Since the data used in the analysis is time series, it was tested for stationarity using Augmented Dickey-Fuller (ADF) Test Statistic. Table 3 shows the results of ADF test. All the variables except rainfall and labour available for agricultural production were non-stationary at level 0 . However, the variables would be stationery at first level difference. But given that there are only 28 observations the option differencing to make them stationary was not considered as it would reduce the observations and the degrees of freedom. To make the observations of the variables stationery, the z-distribution (5) was applied.

\subsubsection{Regression Results}

Parameter estimates for production function are obtained by maximum likelihood-ARCH estimation methods. The detailed regression results are presented in Table 4. The estimated equation appears to be robust as suggested by the F-statistics that is significant at less than 1 percent. A post-estimation ARCH LM test (Table 5), and the Correlogram (Appendix 3) for possible existence of serial correlation in the model is rejected further suggesting the robustness of the estimates.

The variance model indicates that the mean variance $(\omega)$ is constant and close to zero and the coefficient of the ARCH is close to 1 and significant. This suggests that this model specification -which takes into account possible model misspecification e.g. due to variable omission may be closer to reality than making assumptions about the disturbance term (Engle, 1995).

The coefficient of RAIN $D E V$ is positive and significant. This suggests that increase in the deviation in rainfall leads to increase in deviation of crop output recorded. This result is consistent with government policy assertions (MAAIF, 2010) as well as other empirical studies including Asiimwe and Mpuga (2007) that change in rainfall amounts has impact on agricultural production.

Table 4. Maximum likelihood regression of effect of climate variation on output

\begin{tabular}{|c|c|c|c|}
\hline \multicolumn{4}{|c|}{ Production Model: Dependent variable $=$ Output deviation } \\
\hline & Coefficient & z-Statistic & Prob. \\
\hline $\mathrm{C}$ & -0.086 & -1.629 & 0.103 \\
\hline RAIN_DEV & 0.008 & 3.251 & 0.001 \\
\hline TEMP_DEV & 0.109 & 3.639 & 0.000 \\
\hline RAINRAIN_DEV & -0.001 & -2.805 & 0.005 \\
\hline TEMPTEMP_DEV & 0.011 & 0.520 & 0.603 \\
\hline RAINTEMP_DEV & 0.000 & -0.082 & 0.935 \\
\hline AREA_DEV & 0.775 & 6.769 & 0.000 \\
\hline BUGAGRIC_DEV & 0.069 & 2.057 & 0.040 \\
\hline LBR_DEV & -0.015 & -0.123 & 0.902 \\
\hline WAR & 0.073 & 1.395 & 0.163 \\
\hline No of obs. & 28 & & \\
\hline Adjusted $\mathrm{R}^{2}$ & 0.92 & & \\
\hline F-Statistics & 28.4 & & \\
\hline Prob(F-statistic) & 0.000 & & \\
\hline \multicolumn{4}{|l|}{ Variance model } \\
\hline$\Omega$ & 0.002 & 2.926 & 0.003 \\
\hline$\alpha-\operatorname{ARCH}(1)$ & 1.174 & 2.378 & 0.017 \\
\hline$\beta \quad$ - GARCH (1) & -0.033 & -1423 & 0.155 \\
\hline
\end{tabular}

Source: Authors' calculations based on data. 
Table 5. ARCH LM Test for the Serial Correlation in Model

\begin{tabular}{llll}
\hline F-statistic & 0.437219 & Probability & 0.514516 \\
\hline Obs*R-squared & 0.46408 & Probability & 0.495723 \\
\hline
\end{tabular}

Source: Authors' calculations based on data.

The coefficient of RAINRAIN_DEV is significant and negative. This suggests that exponential increase in deviation in rainfall has a negative effect on the deviation in crop output. This results is quite unusual especially in case of where the negative deviation (extensive drought) is observed. Exponential deviation in rainfall (RAINRAIN_DEV) associated with excessive rains lead to increased water moisture availability, an important factor for increased agricultural production, it nevertheless affect the crops' physiology negatively (Hepworth \& Gouldon, 2008) thereby leading to reduced yields. Excessive rains are generally associated with crops loss due to floods that wash away the crops or make them rot in the gardens. Moreover, too much rain affects post-harvest handling of the crops and can result into substantial post-harvest losses. Besides, in the early stages of crop production, excessive rains can lead to erosion of top soils and leaching of soil nutrients, thereby affecting productivity. Other effects of excess rainfall on crop production include poor pollination, seed and fruits formation. Infrastructural breakdown has also been reported as a detrimental effects of excessive rainfall (Mogaka et al., 2006).

The coefficient of TEMP_DEV is positive and significance at less than 1 percent, suggesting that increase in temperature deviation from the mean leads to increase in crops' output deviation. This result is consistent with (Hepworth \& Goulden, 2008; Rosenzweig \& Hillel, 1995) that changes in temperature results to change in agricultural outputs. Prevailing temperature has a number of implications to crop physiology and its immediate environment. It has implications on the rate of evaporation thereby impacting on available water moisture for crop production. It also impacts on a number of physiological processes that lead to the varying levels of productivity among crops e.g. fruiting and photosynthesis (Singh et al., 2007; duPlessis, 2003; Nelson et al., 2009).

The coefficient of AREA_DEV was positive and significant at less than 1 percent level. This relationship is expected in all agricultural systems, as land is the basic factor of production upon which all other factors are engaged in the production process. But the extent to which land remains a critical factor of production in Uganda, as indicated by magnitude of the coefficient suggests the need to for both government and the farmers to pay more attention to other production enhancing inputs -especially physical factors such as seeds and fertilisers than natural resources including land. Besides, the significance of the coefficient of BUGAGRIC_DEV suggests that change government budget support to agricultures for research and provision of extension services and improved inputs has implications of the agricultural outputs achieved. As deviation in government budgetally support increase so does the level of deviation in agricultural output.

The rest of the variables including TEMPTEMP_DEV, RAINTEMP_DEV, LBR_DEV and WAR were found not significant in explaining changes in agricultural crops outputs.

\section{Conclusions and Recommendations}

In this paper, the relationship between climate variation and crop output in Uganda for the period 1981 to 2008 has been examined. The time-varying ARCH model was used to capture the relationships. One of the specific objectives of this study was to examine if indeed there has been any major variation in rainfall and temperature (as key parameters of climate change) from the norm in Uganda over the past three decades. Contrary to previous reports that only suggest about possibility of climate change in Uganda, no significant deviations in rainfall and temperature from the long-term average have been observed from the Department of Meteorology data. What is observed however, are the continuous cyclic pattern of rainfall and temperature variation. The results indicate that while rainfall and temperatures peaked in the early and mid 2000s respectively, overall, they are now gradually declining and are yet to hit the bottom before climbing in respect of the cyclic patterns. This finding, which should be of interest to policymakers as well as researchers, suggests seasonal variation in rainfall and temperature - which contributes to but is not the same as climate change appears to be the major natural phenomena affecting agricultural production in Uganda. As such it is important that knowledge about the changing weather patterns in Uganda should be integrated into the production planning calendar for improved timing of production given that the majority of the cultivators in Uganda are still heavily dependent on rainfall. 
The finding which particularly suggests that volume of rainfall is likely to reduce further from the LT national average of $1250 \mathrm{~mm}$ - over the next 5 or so years, suggests the need for government to support farmers under the Water for Agricultural Production Programme, adopt small-scale irrigation systems as an adaption measure to the likely variability in the volume of water, which is a critical input in crop production. Results have also shown that variation in rainfall and temperature lead to change in crop output. Exponential deviation on amount of rainfall leads to negative effects on the deviation in crop output.

Results also confirm that extensive farming - through increase in area cultivated rather than intensive farming (through use of improved technologies) has remained the predominant form of increasing agricultural output in Uganda. The positive relationship between crop output and government budget allocation to agriculture embraces an optimistic outlook of the effective use of resources to increase agricultural productivity. While government has increased funding to agriculture over the past decade, this result suggests that the scope of increasing Uganda's agricultural output and productivity through budget support still exists.

\section{References}

Asiimwe, J. B., \& Mpuga, P. (2007). Implications of rainfall shocks for household income and consumption in Uganda. RP 168, African Economic Research Consortium, Nairobi, Kenya.

Benhin, J. K. (2008). South Africa crop farming and climate change: an economic assessment of impacts. Global Environmental Change, 18, 666-678. http://dx.doi.org/10.1016/j.gloenvcha.2008.06.003

Bollerslev, T. (1986). Generalised autoregressive conditional heteroskedasticity. Journal of Econometrics, 31, 307-327. http://dx.doi.org/10.1016/0304-4076(86)90063-1

Bollerslev, T., \& Wooldridge, J. M. (1992). Quasimaximum likelihood estimation and inference in dynamic models with time-varying covariances. Econometric Reviews, 11, 143-173. http://dx.doi.org/10.1080/07474939208800229

Campbell, S. D., \& Diebold, F. X. (2003). Weather forecasting for weather derivatives. NBER Working Paper 10141. Retrieved from http://www.Nber.Org/Papers/W10141

Christy, J. R., Norries, W. B., \& McNider, R. T. (2009). Surface temperature variations in East Africa and possible causes. Journal of Climate, 22, 3342-3358. http://dx.doi.org/10.1175/2008JCLI2726.1

du-Plessis, J. (2003). Maize production .agricultural information services. Department of Agriculture, Pretoria, South Africa. $\quad$ Retrieved from http/:Fastonline.org/CD3WD 40/LSTOCK/001/SAInfoPaks/docs/maizeproduction

Engle, R. F. (1982). Autoregressive conditional heteroscedasticity with estimates of the variance of United Kingdom inflation. Econometrica, 50, 987-1007. http://dx.doi.org/10.2307/1912773

Hepworth, N., \& Goulden, M. (2008). Climate change in Uganda: understanding the implication and appraising the response. LTS International Ltd/ DFID Uganda.

Hodrick, R. J., \& Prescott, E. C. (1997). Postwar U.S. business cycles: an empirical investigation. Journal of Money, Credit, and Banking, 29, 1-16. http://dx.doi.org/10.2307/2953682

Horton, B. (1995). Geographical distribution of changes in maximum and minimum temperatures. Atmospheric Research, 37, 101-117. http://dx.doi.org/10.1016/0169-8095(94)00083-P

Government of Uganda. (2010). National Development Plan 2010/11-2014/15. Government of Uganda, Kampala, Uganda.

Intergovernmental Panel on Climate Change. (2007). Summary for policymakers. In Solomon, S., D. Qin, M. Manning, Z. Chen, M. Marquis, K. B. Averyt, M. Tignor, \& H. L. Miller (Eds.), Climate Change 2007: The Physical Science Basis. Contribution of Working Group I to the Fourth Assessment Report of the Intergovernmental Panel on Climate Change. United Kingdom, Cambridge and USA, New York, NY: Cambridge University Press.

Kabubo-Mariara, J., \& Karanja, F. K. (2007). The economic impact of climate change on Kenyan crop agriculture: A Ricardian approach. Global and Planetary Change, 57, 319-330. http://dx.doi.org/10.1016/j.gloplacha.2007.01.002

Kissi, E. (2000). The politics of famine in US relations with Ethiopia 1950-1970. International Journal of Africa Historical Studies, 33(1), 113-131. http://dx.doi.org/10.2307/220260 
Ligon, E., \& Sadoulet. (2007). Estimating the effects of aggregate agricultural growth on the distribution of expenditure. World Bank, Washington D.C.

Ministry of Agriculture, Animal Industry and Fisheries. (2010). Agriculture for food and income security: agricultural sector development strategy and investment plan 2010/11-2014/15. MAAIF, Kampala.

Ministry of Finance, Planning and Economic Development. (2010). The background to the budget 2010/11 fiscal year: strategic priorities to accelerate growth, employment and socio-economic transformation for prosperity. MFPED, Kampala, Uganda.

Mogaka. H., Gichere, S., Davis, R., \& Hirji, R. (2006). Climate variability and water resources degradation in Kenya improving water resources development and management. World Bank Working Paper No. 69 . The World Bank, Washington DC.

Moula, E. L. (2009). An Empirical assessment of the impact of climate change on smallholder agriculture in Cameroon, Global and Planetary Change, 67, 205-208. http://dx.doi.org/10.1016/j.gloplacha.2009.02.006

National Environment Management Authority [NEMA]. (2010). Uganda atlas of our changing environment. UNEP, Nairobi.

Nelson, G. C., Rosegrant, M. K., Koo, J., Robertson, R., Sulser, T., Zhu, T, ... Lee, D. (2009). Climate change: impact on agriculture and costs of adaptation. International Food Policy Research Institute, Washington, D.C. October 2009.

Odingo, S. R. (2008). Climate change and economic development-issues, challenges and opportunities for Africa in the decades ahead (pp. 1-22). In proceeding for AERC Senior Policy Seminar X on climate change and economic development in Sub-Saharan Africa. Adddis Ababa, Ethiopia 7-9 April 2008.

Oxfarm. (2008). Turning up the heat: climate change and poverty in Uganda. Oxfarm GB.

Rosenzweig, C., \& Daniel, H. (1995). Potential impacts of climate change on agriculture and food supply. Consequences, $\quad$ 1(2). Retrieved $\quad$ February, $2011, \quad$ from http://www.climate.org/resources/climate-impacts/agriculture/index.html

Schlenker, W., \& Lobell, D. B. (2010). Robust negative impacts of climate change on African agriculture. Environmental Research Letters, 5(1). http://dx.doi.org/10.1088/1748-9326/5/1/014010

Singh, R. P., Prasad, P. V., Sunita, K., Giri, S. N., \& Reddy, R. K. (2007). Influencing of high temperate and breeding for heat tolerance in cotton: a review. Elsevier Inc.

Uganda Bureau of Statistics. (2008). Statistical Abstract 2008. UBOS, Kampala Uganda.

Uganda Bureau of Statistics. (2009). Statistical Abstract 2009. UBOS, Kampala Uganda.

United Nations. (1997). Africa Statistical Yearbook. Volume II; East Africa. UN, New York, USA.

United Nations Food and Agriculture Organisation [FAO]. (2008). Climate change and food security: a framework document. FAO, Rome, Italy.

United Nations Environment Programme [UNEP]. (2009). Climate change science compendium 2009. UNEP, Nairobi, Kenya.

World Bank. (2009). Making development climate resilient: A World Bank strategy for Sub Saharan Africa. World Bank Report No. 46947-AFR. World Bank, Washington D.C., USA. http://dx.doi.org/10.1596/978-0-8213-7946-2

World Bank. (2010). World Development Report 2010: Development and climate change. World Bank, Washington D.C., USA.

\section{Notes}

Note 1. Long term in the case of climate change is at least 30 years. According to popular a definition; climate change is a change in the statistical distribution of weather over periods of time that range from decades to millions of years. http://en.wikipedia.org/wiki/Climate_change

Note 2. The Hodrick-Prescott filter is a mathematical tool used especially in real business cycle theory to decompose the economic series of interest into a permanent trend (trend) and a transitory deviation (cycle) (Hodrick \& Prescott, 1997). 
Appendix 1. Comparison of rainfall means from various rainfall station

\begin{tabular}{cccccc}
\hline Source & SS & df & MS & F Prob & $>$ F \\
\hline Between groups & 17723504.4 & 9 & 1969278.27 & 42.68 & 0 \\
Within groups & 13148788.8 & 285 & 46136.1011 & & \\
Total & 30872293.2 & 294 & 105007.8 & & \\
\hline
\end{tabular}

Bartlett's test for equal variances: chi2 $(9)=59.4$ Prob $>$ chi2 $=0.000$

Cross comparison of station mean rainfall (Bonferroni)

\begin{tabular}{|c|c|c|c|c|c|c|c|c|c|}
\hline $\begin{array}{l}\text { Row Mean-| } \\
\text { Col Mean }\end{array}$ & Jinja & Masindi & Gulu & Kasese & Entebbe & Tororo & Kabale & Soroti & Kampala \\
\hline \multirow[t]{2}{*}{ Masindi } & 29 & & & & & & & & \\
\hline & 1.0 & & & & & & & & \\
\hline \multirow[t]{2}{*}{ Gulu } & 153 & 124 & & & & & & & \\
\hline & 0.6 & 1.0 & & & & & & & \\
\hline \multirow[t]{2}{*}{ Kasese } & -446 & -475 & -599 & & & & & & \\
\hline & 0.0 & 0.0 & 0.0 & & & & & & \\
\hline \multirow[t]{2}{*}{ Entebbe } & 316 & 287 & 163 & 762.4 & & & & & \\
\hline & 0.0 & 0.0 & 0.4 & 0.0 & & & & & \\
\hline \multirow[t]{2}{*}{ Tororo } & 195 & 166 & 42 & 641.2 & -121.2 & & & & \\
\hline & 0.0 & 0.1 & 1.0 & 0.0 & 1.0 & & & & \\
\hline \multirow[t]{2}{*}{ Kabale } & -293 & -322 & -446 & 153 & -609 & -488 & & & \\
\hline & 0.0 & 0.0 & 0.0 & 0.3 & 0.0 & 0.0 & & & \\
\hline \multirow[t]{2}{*}{ Soroti } & 36 & 7 & -117 & 482 & -280 & -159 & 329 & & \\
\hline & 1.0 & 1.0 & 1.0 & 0.0 & 0.0 & 0.2 & 0.0 & & \\
\hline \multirow[t]{2}{*}{ Kampala } & -57 & -86 & -210 & 389 & -373 & -252 & 236 & -93.1 & \\
\hline & 1.0 & 1.0 & 0.0 & 0.0 & 0.0 & 0.0 & 0.0 & 1.0 & \\
\hline \multirow[t]{2}{*}{ Mbarara } & -401 & -430 & -554 & 45 & -718 & -596 & -108 & -437 & -344 \\
\hline & 0.0 & 0.0 & 0.0 & 1.0 & 0.0 & 0.0 & 1.0 & 0.0 & 0.0 \\
\hline
\end{tabular}

Appendix 2. Description of Uganda climatic zones and representative station selected for the study

\begin{tabular}{|c|c|c|}
\hline Zone & Representative stations & General description \\
\hline Lake Victoria Basin & Jinja, Entebbe, Kampala & $\begin{array}{l}\text { Extends around } 48-64 \mathrm{~km} \text { around Lake Victoria. } \\
\text { Rainfall varies } 1250-2000 \mathrm{~mm} \text { p.a }\end{array}$ \\
\hline Western Uganda & Masindi, Kabale & $\begin{array}{l}\text { Covers plateu, escarpment, highlands and } \\
\text { mountains of western. Rainfall 1250-2000 } \mathrm{mm} \\
\text { per annum }\end{array}$ \\
\hline Acholi-Kyoga & Gulu, Soroti & $\begin{array}{l}\text { Northern and part of eastern plateau. Rainfall } \\
1250-1500 \mathrm{~mm} \text { p.a }\end{array}$ \\
\hline Southern & Mbarara, & $\begin{array}{l}\text { eastern to south western. Rainfall averages } \\
875-1125 \mathrm{~mm} \text { p.a }\end{array}$ \\
\hline Mt. Elgon & Tororo & $\begin{array}{l}\text { Between L Victoria and Mt Elgon. Rainfall } \\
1000-1500\end{array}$ \\
\hline Karamoja & Kasese & $\begin{array}{l}\text { On north eastern and the floor of the Rift valley } \\
\text { on the extreme west. Rainfall } 300-600\end{array}$ \\
\hline
\end{tabular}

Source: NEMA, 2010 Uganda Atlas of Changing Environment. 
Appendix 3. Correlogram of standardised residuals squared

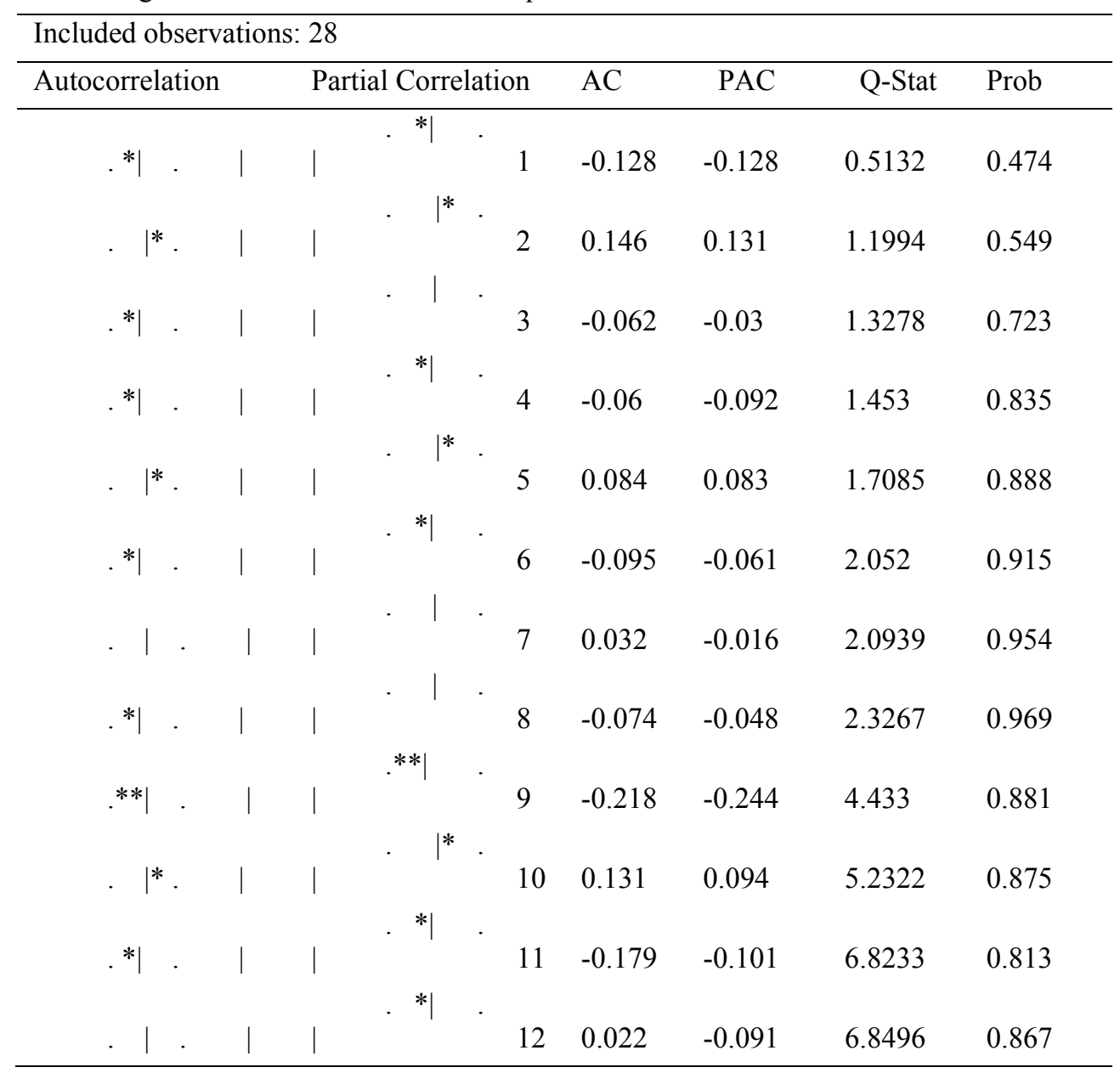

\section{Copyrights}

Copyright for this article is retained by the author(s), with first publication rights granted to the journal.

This is an open-access article distributed under the terms and conditions of the Creative Commons Attribution license (http://creativecommons.org/licenses/by/3.0/). 